\title{
$\mathrm{PD}-2$
}

\section{Changing Concepts in Pediatric Urology}

兵庫医科大学泌尿器科

島博基

性分化異常

性分化異常における臨床的分類は男性仮性半陰陽male pseudohermaphroditism、 女性仮性半陰陽female pseudohermaphroditism、真性半除陽true hermaphroditism、 その他の関連疾患（XX男性、クラインフェルター症候群、ターナー症候群、 ミュラー管遺残症候群、母体へのプロゲステロンなどの投与など）に分かれる。 生殖腺と外生殖器の異常の有無から半陰陽およびその関連疾患を上記の分類に 従った表を提示する（当日入口にて配布）。これらの疾患の背景を理解する上で 大きく変ったことはSRYなどの生殖腺関連遺伝子やアンドロゲン受容体、 $5 \alpha$ 一還元酵素、ミュラー管退縮物質、アロマターゼ酵素、副腎のステロイド合成 酵素遺伝子の配列が決定されたことである。このため生殖腺形成および性分化 機構の解明が進み、疾患の病態が明らかにされ、各疾患に対して確立した治療 方針を決めることが出来るようになった。今回はこれらの新しい知見が疾患の 診断と治療方針にどのように関係するかを述べ、臨床的には最小限の検査で治 療方針を決めて行くことが出来ることを述べる。 